\title{
APLIKASI MIKROFOTOGRAFI UNTUK MENGEKSPLORASI JENIS-JENIS CYANOPHYTA
}

\author{
Widodo \\ Program Studi Pendidikan Biologi, Fakultas Sains dan Teknologi \\ Universitas Islam Negeri Sunan Kalijaga Yogyakarta \\ Email: wwidodo594@gmail.com. \\ Diterima 30 Mei 2014 disetujui 11 Juli 2014
}

\begin{abstract}
Archiving and dissemination of data, techniques, and observations of Cyanophyta required for optimization of succesfully low plant systematics studies. This paper aims to present the preparation techniques and the results of Cyanophyta algae observing with light microscope and digitaly camera. Sources accurate specimen was also informed by the author repeatedly experience in organizing learning plant systematics. Preparation and microscopic observation Cyanophyta consists of preparation of accurate source of specimens, microscopic observation to obtain optimum picture of the object and focus, shooting or recording images using a digital camera. The image files are stored and are equipped with a scale.Results of preparation, observation and shooting showed that cells and colonies all Cyanophyta (Oscillatoria, Anabaena, Nostoc ) has a similar size range that requires preparation to optimize the use of the same light microscop . Cells of Cyanophyta colonies can be seen clearly in the eyepiece magnification of 10x and 40x objective. Less than that magnification, The thalus of Cyanophyta difficult to observe because of the relatively small cell size compared to the size of eukaryotic cells. By shooting with digitaly camera, microscopy observation images can be captured as digital specimen. Observing the digitaly specimen does not change depending on season and time. The digital images can also be analyzed and studied further.
\end{abstract}

Keyword : microphotography, digitaly specimen, cyanophyta, low plant systematics

\section{PENDAHULUAN}

Penggunaan gambar dan sketsa obyek organisme dalam pembelajaran biologi pada umumnya dan sistematika tumbuhan khususnya lazim dan sering dilakukan. Permasalahan timbul jika gambar kurang mencerminkan ciri sebenarnya atau tidak sesuai kondisi aslinya. Permasalahan juga timbul jika obyek organisme berukuran mikroskopis dan sulit preparasinya. Alga mikroskopis terutama Cyanophyta memiliki ukuran sel yang relatif kecil dan sulit diamati dengan mikroskop cahaya biasa. Teknik pengamatan sel Cyanophyta memerlukan kehalusan ketrerampilan teknik yang tinggi. Dengan pemakaian mikroskop cahaya yang baik lensanya akan diperoleh hasil amatan yang baik.

Pengenalan specimen-specimen mikroskopis dalam pembelajaran sistematika tumbuhan rendah secara umum, kajian kajian khusus tentang Cyanophyta, kajian-kajian interdisipliner yang melibatkan Cyanophyta biasanya digunakan gambar sketsa dari buku-buku lama. Sketsa dalam buku lama seringkali kurang jelas, tidak mencerminkan struktur asli/alamiahnya. Pembelajaran seperti ini berujung pada kompetensi menghafalkan gambar-gambar tetapi tidak mendapatkan fakta asli specimen. Disisi lain, pembuatan stok obyek specimen, foto, gambar, video tentang Cyanophyta relatif sulit diadakan karena beberapa alasan yaitu kurangnya pengalaman mengenal distribusi Cyanophyta di alam, sulit menemukan sumber utama specimen karena minimnya eksplorasi, teknik preparasi mikroskopi yang tidak kompeten, rendahnya dokumentasi visual dalam kegiatan pengamatan dalam praktikum. Permasalahan terakhir mendorong 
kesadaran bersama bahwa dokumentasi dan pengarsipan digital hasil pengamatan dalam praktikum relatif penting untuk meningkatkan capaian pembelajaran.

Kemajuan dan kemudahan teknik fotografi juga perlu diterapkan untuk optimalisasi capaian pembelajaran sistematika tumbuhan rendah dan kajiankajian mengenai Cyanophyta. Data fotografi pada dasarnya merupakan data specimen digital (Baskauf dan Kirchof, 2008) sebagai data base yang penting untuk identifikasi. Data specimen digital bermanfaat sebagai pengganti specimen asli.

Hasil pengamatan specimen Cyanophyta yang berkualitas baik perlu didokumentasikan dalam bentuk file gambar digital. Dokumentasi file gambar digital tersedia sebagai sumber belajar fungsional, kontekstual, riil, mudah diakses bagi guru, dosen, siswa mahasiswa.

Tulisan ini mempresentasikan teknik preparasi dan hasil pemotretan/perekaman video algae Cyanophyta berupa gambargambar hasil mikrofotografi Cyanophyta representatif di lingkungan sekitar.

\section{METODE}

Bahan-bahan yang digunakan ialah sumber specimen Cyanophyta berupa: air genangan dalam pot tanah liat beserta kerokan dinding pot yang tergenang; tanah atau batuan, lantai, tanah lembab, tanah basah berwarna hijau; paku air Azolla pinnata. Alat-alat yang digunakan terdiri: mikroskop cahaya, gelas obyek, gelas penutup, objective micrometer, jarum preparat, kamera digital (Sony Cyber-Shot DSC-W180). Kamera digital berkualitas baik, minimal 6 Megapixel dipersiapkan bersamaan mempersiapkan mikroskop cahaya dan perlengkapannya.

Teteskan air bercampur tanah lembab pada gelas obyek dengan pipet tetes. Pilih bagian larutan tanah yang berwarna hijau kebiruan kemudian tutup dengan gelas penutup kemudian letakkan pada meja benda mikroskop.

Dengan perbesaran lemah, fokuskan obyek. Ganti/putar lensa obyektif ke perbesaran kuat $(40 \mathrm{x}, 100 \mathrm{x})$ tanpa merubah posisi gelas obyek pada meja benda. Fokuskan mikrometer secara hati-hati dan geser pula glas obyek secara pelan-pelan untuk mendapatkan gambar dan bagian gambar terjelas.Tempelkan/sambungkan lensa kamera digital dengan bantuan holder (dirancang sendiri) pada bagian lensa okuler tubus mikroskop cahaya. Lakukan pemotretan dengan autofokus. Ulangi pemotretan hingga diperoleh gambar terbaik. Specimen Anabaena pada literatur lama dapat diperoleh pada lapisan korteks akar bunga karang Cycas rumphii. Species Anabaena adalah Anabaena cycadeae yang hidup simbiotik dengan akar Cycas.

Berdasarkan pengalaman proses praktikum penulis, Anabaena azollae mudah ditemukan pada permukaan bawah daun paku air Azolla pinnata melalui preparasi squash (pencet) segar di atas gelas obyek. Pengamatan dan pemotretan selanjutnya sama dengan teknik pada Oscillatoria. Nostoc banyak di temukan pada permukaan batuan yang terendam air, dinding pot tanaman air, dinding selokan terendam air, genangan air dalam pot yang sudah lama. Keberadaan Nostoc biasanya bersama-sama Cyanophyta berbentuk filamen lainnya dan alagae hijau berbentuk filamen.

Pengamatan dan pemotretan selanjutnya sama dengan teknik pada Oscillatoria dan Anabaena.

\section{HASIL DAN PEMBAHASAN}

\section{Oscillatoria sp.}

Hasil pengamatan specimen Oscillatoria pemakaian lensa Okuler perbesaran 10x dan Obyektif 10x ditunukkan oleh Gambar 1.

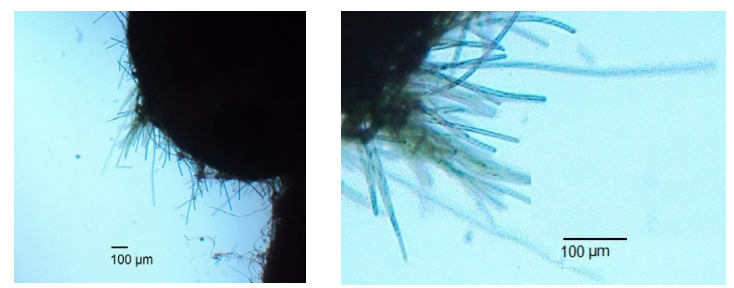

Gambar 1. Filamen-filamen Oscillatoria pada Perbesaran 10x40. 
Gambar 1 memperlihatkan struktur filamen Oscillatoria yang menempel pada substrat. Panjang rata-rata filamen Oscillatoria berkisar 100-200 $\mu \mathrm{m}$. Pengamatan menunjukkan bahwa filamen Oscillatoria dapat melakukan pemanjangan dua kali lipat ukuran panjang rata-rata.

Pengamatan Oscillatoria dengan memakai lensa Okuler perbesaran 10x dan Obyektif 40x ditunjukkan Gambar 2 dan 3. Unit sel penyusun filamen tersusun rapat sehingga satuan sel kurang jelas batasnya. Ujung filamen tumpul membulat (Gambar 3). Cahaya lampu mikroskop menimbulkan respon gerakan meluncur, memanjangmemendek, membentuk kumpulan koloni filamen yang lebih teratur dan sejajar.

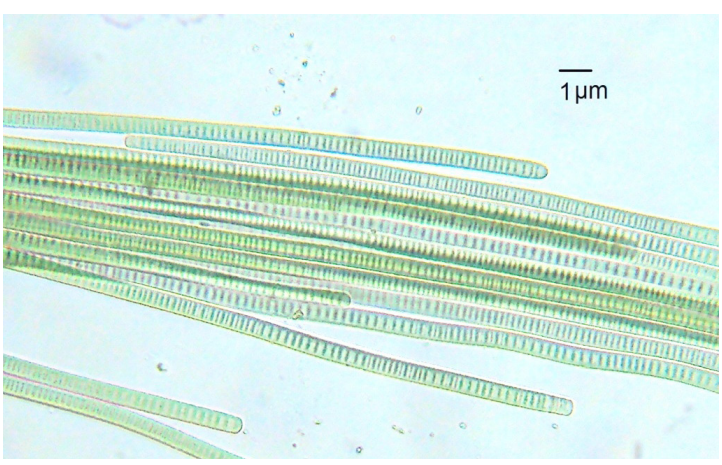

Gambar 2. Struktur filamen Oscillatoria.

Gambar 3 menunjukkan bahwa kumpulan filamen Oscillatoria yang banyak dapat mengadakan gerakan melipat melingkar untuk membentuk susunan filamen yang sejajar dan teratur. Gerakan meluncur, memanjang dan memendek tampak jelas dan dapat direkam dengan kamera digital yang digunakan dalam pengamatan ini.

A

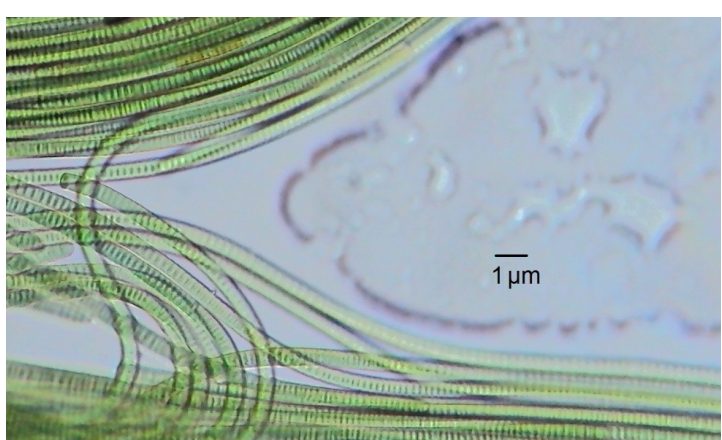

B

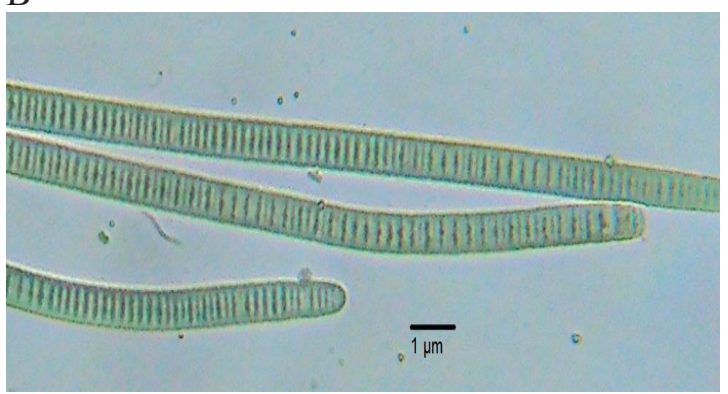

C
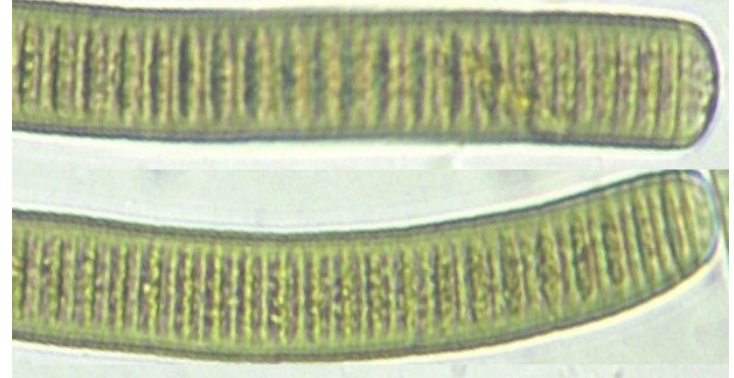

Gambar 3. A. Posisi Kumpulan Filamen Oscillatoria Dalam Keadaan Padat. B. Filament Memanjang. C. Filamen Memendek Dengan Ujung Membulat.

Gambar-gambar Oscillatoria yang direkam dalam bentuk file gigital pada pengamatan ini lebih jelas dan autentik dibandingkan dengan gambar-gambar sketsa dan foto dalam buku-buku literatur antara lain Gembong (2009) maupun temuan-temuan dalam jurnal penelitian seperti Naz et al. (2004), Sompong et al. (2008), Prihantini et al. (2008), Bhavani et al. (2013), Joishi (2014).

\section{Anabaena sp}

Hasil pengamatan dan pemotretan specimen Anabaena dengan memakai lensa Okuler perbesaran 10x dan Obyektif 40x ditunjukkan Gambar 4. 

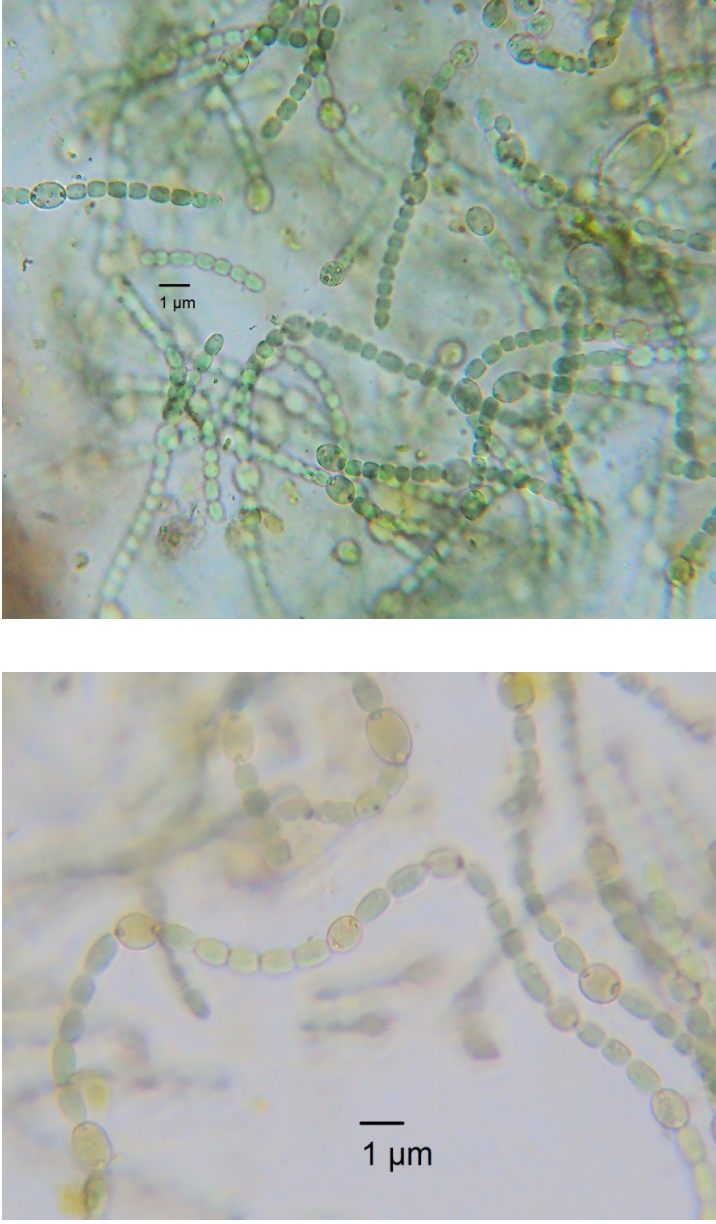

Gambar 4. A. Koloni Filament Anabaena Pada Permukaan Bawah Daun Azolla pinnata.

Filamen Anabaena tampak serupa untaian manik-manik atau tasbih. Pada permukaan bawah daun paku air Azolla pinnata, salah satu ujung filamen melekat pada jaringan spon sedangkan ujung filamen lainnya menggantung bebas. Proses pemencetan (squash) daun Azzolla secara perlahan dimaksudkan agar filamen Anabaena dapat terurai secara bebas sehingga mudah diamati di mikroskop.

Sel-sel penyusun filamen berbentuk oval, lonjong sampai bulat. Terdapat dua tipe sel pembentuk filamen yaitu sel-sel utama penyusun filamen berbentuk lonjong berukuran lebih kecil dan sel-sel heterocyst berbentuk oval sampai bulat dan berukuran lebih besar. Sel heterocyst berada diselasela 2 sampai 7 sel-sel filamen utama. Detail struktur filemen Anabaena ditunjukkan Gambar 5.

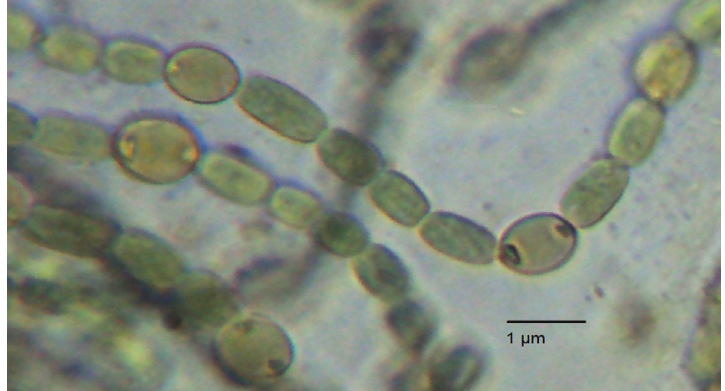

Gambar 5. Struktur Detail Sel-Sel Anabaena azollae. Tanda Panah Menunjukkan Sel Heterocyst.

Struktur filamen Anabaena yang diperoleh pada pengamatan ini relevan dengan gambar dan ilustrasi hasil penelitian Sompong et al. (2008), Siahbalaei et al. (2012), Bishop (2014), Bhavani et al. (2013), Joishi (2014).

\section{Nostoc sp}

Hasil pengamatan dan pemotretan specimen Nostoc memakai lensa Okuler perbesaran 10x dan Obyektif 40x ditunjukkan Gambar 6. Gambar 6A menunjukkan kumpulan filamen Nostoc dan diantaranya terdapat alge kersik Diatomae. Gambar 6B merupakan filamen tunggal.

Filamen Nostoc menunjukkan struktur kaku tetapi lentur seperti Oscillatoria tetapi lebih ramping. Satuan sel-sel Nostoc lebih jelas dibandingkan Oscillatoria dan berbentuk membulat kuboid. Tiap satuan filamen terdapat sel heterocyst berbentuk oval. Ukuran dan bentuk heterocyst pada Nostoc relatif mirip dengan sel lainnya (Gambar 7).

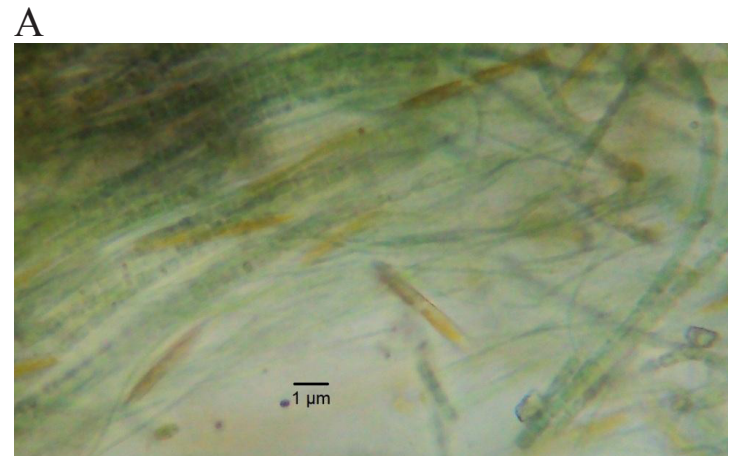


B

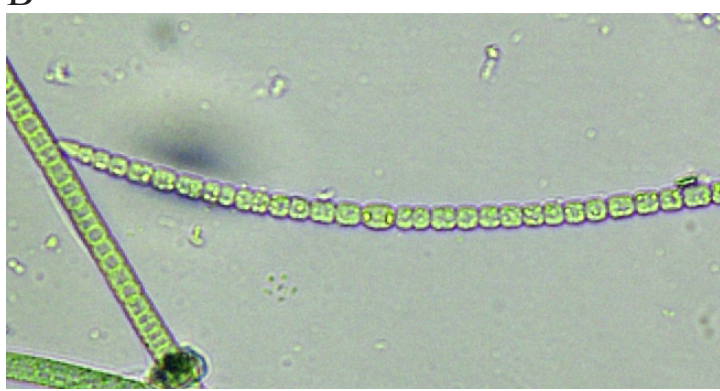

Gambar 6. Filamen Nostoc. A. Kumpulan Filamen. B. Satuan Filamen.

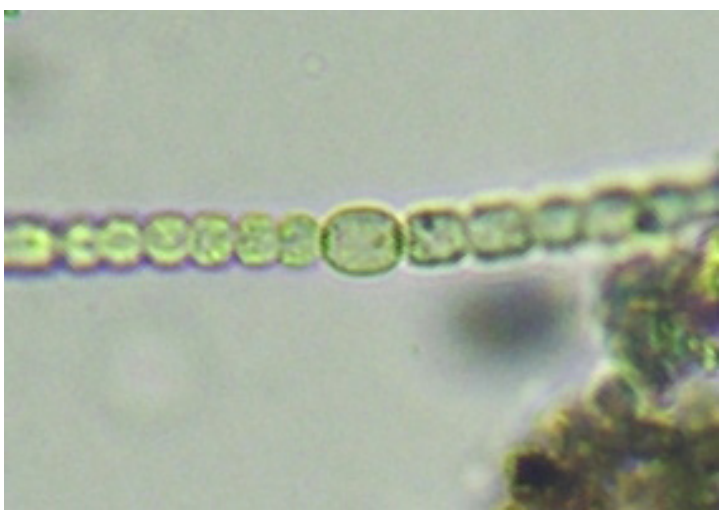

Gambar 7. Sel Heterocyst Filamen Nostoc sp. (Tanda Panah).

Struktur sel Nostoc yang diperoleh mirip dengan hasil penelitian Siahbalaei et al. (2012), Bishop (2014). Berdasarkan data-data hasil preparasi dan pengamatan di atas diperoleh gambar-gambar autentik struktur talus Cyanophyta di lingkungan sekitar. Sruktur koloni dan habit specimen dapat diamati pada perbesaran lemah sedangkan bentuk sel dapat diamati dengan perbesaran kuat.

Pengamatan

mikroskopis

Cyanophyta memerlukan ketelitian dan penguasaan prediksi ukuran agar ditemukan obyek dalam perbesaran lemah maupun perbesaran kuat karena secara umum sel-selnya berukuran kurang dari $1 \mu \mathrm{m}$. Perbandingan ukuran Oscillatoria sebagai salah satu Cyanophyta dengan Spyrogyra (salah satu algae hijau Chlorophyta) ditunjukkan Gambar 8. Salah satu kesulitan pengamatan mikroskopis Cyanophyta adalah menemukan obyek atau specimen secara cepat karena ukuran yang jauh lebih kecil dibandingkan sel-sel algae maupun sel-sel tumbuhan eukariotik.

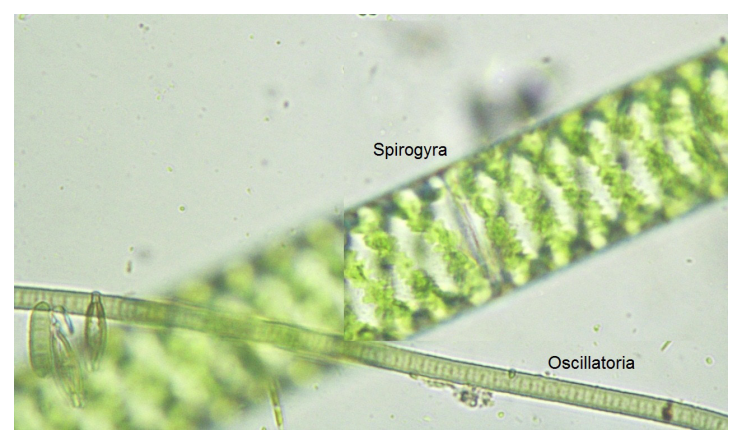

Gambar 8 Perbandingan ukuran filamen Oscillatoria dengan Spyrogyra

Kepekaan prediktif dan pengalaman memperoleh sumber specimen penting untuk medapatkan specimen yang cukup dan representatif untuk diamati. Kepekaan ini perlu dibentuk dengan usaha-usaha eksplorasi dan didasarkan pula sumbersumber informasi yang ada pada literatur. Minimnya upload hasil-hasil pengamatan specimen Cyanophyta di internet oleh situs-situs dari Indonesia menunjukkan kurangnya kajian-kajian tentang Cyanophyta khususnya aspek struktur. Oleh karena itu data dan teknik preparasi dalam tulisan ini diharapkan memberikan solusi praktis untuk kajian tentang Cyanophyta.

\section{SIMPULAN}

1. Specimen Cyanophyta dari genus Oscillatoria, Anabaena, Nostoc mudah ditemukan di lingkungan pada kondisi yang tepat.

2. Diperlukanketelitian, kecermatandan akurasi prediksi dalam mendapatkan specimen dan pengamatan mikroskopi secara optimal karena ukuran sel yang sangat kecil serta mikrohabitat spesifik.

3. Hasil pengamatan mikroskopis Cyanophyta perlu diabadikan dalam bentuk file gambar digital atau video digital agar dapat dipakai untuk kepentingan penelitian dan pembelajaran.

4. Kamera digital dengan ukutan permukaan diafragma lensa yang kompatibel dengan diameter tubus mikroskop dapat dimanfaatkan untuk 
pemotretan specimen-specimen Cyanophyta yang sedang diamati.

\section{DAFTAR PUSTAKA}

Baskauf, S. J., Kirchoff, B. K. 2008. Digital Plant Image As Speciments: Toward Standards for Photographing Living Plants. Vulpia, 7:16-30.

Bhavani, B., Manoharan, C., Vijayakumar, S. 2013. Studies on Diversity of Cyanobacteria from Temples and Monuments in India. International Journal of Environment, Ecology, Family and Urban Studies. 3 (1): 2132

Bishop, W. ........Biology and Control of Algae. NC: SePro Research and Technology Campus.

Joishi, M. S., Studies on Annual Variation in Species Diversity of Cyanobacteria in Four Rivers of Western Ghats Region, Karnataka, India. International Research Journal of Plant Science, 5 (3): 43-52.

Leggett, R and Kirchoff, B. K. 2011. Image use in field guides and identification keys: review and recommendations. AoB PLANTS, 2011:1-37.

Naz, S., Hasan, M. U., Shameel, M. 2004. Biodiversity of Oscillatoria (Nostocophyceae, Cyanophyta) from Northern Areas of Pakistan. Pak. J. Bot., 36 (3): 503-530.

Prihantini, N. B., Wardhana, W., Hendrayana, D., Widyawan, A., Ariyani, Y., Rianto, R. 2008. Biodiversitas Cyanobacteria dari Beberapa Situ/Danau di Kawasan Jakarta, Depok, Bogor Indonesia. Makara Sains, 12 (1): 44-54.

Siahbalaei, R., Afsharzadeh, S., Shokravi, S. 2012. New Morphospecies of Heterocys $\backslash$ tous Cyanophyta from Paddy Field of Golestan Province, Iran. Iran J, Bot., 18 (2): 311-317.

Sompong, U., Anuntalathochai, S., Cutler, R. W., Castenhotz, R. W., Paerapornpisae, Y. 2008. Morphological and Phylogenic Diversity of Cyanobacteriae
Population in Six Hotsprings of Thailand. Science Asia, 34: 153-162.

Tjitrosoepomo, G. 2009. Taksonomi Tumbuhan. Yogyakarta: Gadjah Mada University Press. 